\author{
Sylwester Kozak, \\ Warsaw University of Life Sciences - SGGW
}

Agata Wierzbowska,

Kobe University

\title{
BANK EFFICIENCY AND CONCENTRATION OF THE BANKING SECTOR IN THE CEE COUNTRIES
}

\begin{abstract}
The relationship between the structure of the banking market and efficiency of banks has been a subject of many studies for several decades. There is no uniform opinion on the correlation between these variables. The goal of the research is to investigate this relationship for 96 banks operating in eleven CEE countries in the years of 2005-2017. Bank efficiency scores are assessed with the SFA method and regressed with bank and macroeconomic characteristics. The results show that the efficiency of banks is positively affected by the concentration of the market on which they operate, as well as by the size of individual banks. This relationship is valid for all examined countries. Additionally, bank efficiency is positively impacted by improving the banking system. On the other hand, the GDP per capita, inflation rate and bank capital ratio are not conducive to bank efficiency.
\end{abstract}

Key words: CEE countries, bank, efficiency, market concentration JEL codes: G10, G15, G21

\section{Introduction}

Banks efficiency in recent decades has been an important subject for academics and policy makers ${ }^{1}$. Among them, relatively frequent studies include the relationship between the banking market concentration and efficiency of banks. However, the conclusions from these studies are relatively divergent. Some of them indicate a positive

\footnotetext{
${ }^{1}$ G. Casu, C. Girardore, Bank competition, concentration and efficiency in the single European market, The Manchester School vol. 74(4)/2006, p. 441-468; A. Berger, I. Hasan, M. Zhou, Bank ownership and efficiency in China: what will happen in the world's largest nation?, Journal of Banking and Finance vol. 33/2009, p. 113-130; M. Duygun, V. Sena, M. Shaban, Schumpeterian competition and efficiency among commercial banks, Journal of Banking and Finance vol. 37/2013, p. 5176-5185; R. Mesa, H. Sánchez, J. Sobrino, Main determinants of efficiency and implications on banking concentration in the European Union, Spanish Accounting Review vol. 17(1)/2014, p. 78-87; M. Nițoi, C. Spulbar, An Examination of Banks' Cost Efficiency in Central and Eastern Europe, Procedia Economics and Finance vol. 22/2015, p. 544-551; T. Silva, S. Guerra, B. Tabak, R. de Castro Miranda, Financial networks, bank efficiency and risk-taking, Journal of Financial Stability vol. 25(C)/2016, p. 247-257; J. Peng, V. Jeng, J. Wang, Y. Chen, The impact of bancassurance on efficiency and profitability of banks: Evidence from the banking industry in Taiwan, Journal of Banking and Finance vol. 80/2017, p. 1-13; P. Avramidis, Ch. Cabolis, K. Serfes, Bank size and market value: The role of direct monitoring and delegation costs, Journal of Banking and Finance vol. 93/2018, p. 127138 .
} 
impact of banking sector concentration on bank performanc, ${ }^{2}$ while others show the opposite direction of the dependence ${ }^{3}$ or do not find any significant relationship ${ }^{4}$. Similar discrepancies occur in the assessment of the possible impact of individual factors, including of a bank's market share on its efficiency. The difference between obtained results may come from the fact that these relationships were examined in various macroeconomic conditions with various timeframes, and on sets of banks operating in different geographical regions.

The goal of our research is to assess how the level of the banking market concentration affects efficiency of banks in the CEE region in the years from 2005-2017. Additionally, we check the impact of the market share of these banks on their efficiency. The time range of the research includes two important events that could have a significant impact on the banks' activity, i.e. the global financial crisis of 2007-2009 and the public finance crisis in some euro area countries in 2011-2012. The study covers 96 banks operating in eleven CEE countries. The importance of the issue of ensuring effective delivery of credit and other banking services to enterprises and households and effective implementation of the monetary policy of the central bank make the problem of studying the level of banks' efficiency an important topic for both academics and supervisory institutions. The study fills the existing gap in literature in this respect and casts a new look at the shape of this relationship, while taking into account some macroeconomic variables, such as: GDP per capita, inflation rate, level of development of the banking sector, as well as banks' capital ratio.

The rest of the article consists of three sections and conclusions. The first presents conclusions from the literature review, the second presents data and methods used in the research, and the third discusses the results of the research. The entire study is summarized in the conclusions.

\section{Market structure and efficiency - existing studies}

The economic literature does not provide a definite answer on the question about the impact of the structure of the banking market on banks' performance. The results of the research are usually explained with two theories: the market power (MP) theory and the efficient structure (ES) theory. The first one uses two models for describing the market structure-performance relationship, i.e. the structure-conduct-performance hypothesis (SCP) and the relative market power hypothesis (RMP). The SCP hypothesis assumes that in a more concentrated market banks set prices that are more favorable for

\footnotetext{
${ }^{2}$ A. Berger, R. Demsetz, P. Strahan, The consolidation of the financial services industry: Causes, consequences, and implications for the future, Journal of Banking and Finance vol. 23/1999, p. 135-194; M. Haynes, S. Thompson, The productivity effects of bank mergers: Evidence from the UK building societies, Journal of Banking and Finance vol. 23/1999, p. 825-846; J. Bikker, K. Haaf, Competition, concentration and their relationship: An empirical analysis of the banking industry, Journal of Banking and Finance vol. 26(11)/2002, p. 2191-2214; D. Amel, C. Barnes, F. Panetta, C. Salleo, Consolidation and efficiency in the financial sector: A review of the international evidence, Journal of Banking and Finance vol. 28/2004, p. 2493-2519.

${ }^{3}$ S. Rhoades, Efficiency effects of horizontal (in-market) bank mergers, Journal of Banking and Finance vol. 17(2-3)/199, p. 411-422; E. Mamatzakis, R. Matousek, A. Vu A.N., What is the impact of bankrupt and restructured loans on Japanese bank efficiency?, Journal of Banking and Finance vol. 72/2017, p.187-202.

${ }^{4} \mathrm{~N}$. Avkiran, The evidence on efficiency gains: The role of mergers and the benefits to the public, Journal of Banking and Finance vol. 23(7)/1999, p. 991-1013; G. Casu, C. Girardore, Bank competition, concentration and efficiency in the single European market, The Manchester School vol. 74(4)/2006, p. 441-468.
} 
themselves and earn higher profits. In turn, the RMP hypothesis assumes that more favorable prices could be introduced only by banks with larger market shares, regardless in how concentrated are the markets in which they operate.

The relationship between the market structure and companies' performance was for the first time noticed by Mason ${ }^{5}$. He stated that although the behavior of enterprises may depend on economic conditions, the level of market concentration is the main determinant in their decision to increase prices, which leads to improvement of results. An important stage in the development of the SCP hypothesis is shown in an article by Bain $^{6}$, in which he stated that the smaller the number of enterprises in a market, and the higher the concentration, leads to behaviors indicating a decrease in competition. As a result, companies increase prices and achieve higher profits, which are carried out at the expense of reducing customers' wealth. Such conduct has been noticed in the research conducted on banks over the last few decades. Gilbert noticed that in the 1960s, due to the change in the legal requirements referring to the effects of bank mergers on the competition, large US banks were able to offer lower deposit rates and higher loan rates and as a result raise their profits ${ }^{7}$. Garcia-Herrero et al. ${ }^{8}$ and Fu et al. ${ }^{9}$ tested the market structure-performance relationship in China and Asia Pacific countries in the years 19972004 and 2007-2008, respectively, and found that banks are more efficient in less concentrated banking markets. Similarly, Maudos and Fernandez de Guevara, ${ }^{10}$ based on research of the European banking sector in the years 1995-2001, stated that the increase in concentration and market power leads to a fall in efficiency.

The efficient structure (ES) theory was formulated by Demsetz and states that more efficient firms grow at the expense of less competitive competitors ${ }^{11}$. In the banking sector efficient banks can lower the prices of their products, become more competitive and gain new customers. It enables them to increase their market share by displacing or taking over less competitive competitors. Such a process leads to increased concentration of the entire banking market. In one of the earliest studies on this subject, Evanoff and Fortier explain that an increase in the concentration of local bank markets in the USA in the 1970s and 1980s was caused when more efficient banks acquired less competitive entities $^{12}$. In recent years, using the ES theory, Homma et al. examined Japanese banks operating in the period of 1974-2005 and explained that efficient large banks

\footnotetext{
5 E. Mason, Price and Production Policies of Large-Scale Enterprise, American Economic Review vol. 29(1)/1939, p. 61-74.

${ }^{6}$ J. Bain, Relation of Profit Rates to Industry Concentration, Quarterly Journal of Economics vol. 55/1951.

${ }^{7}$ R. Gilbert, Bank market structure and competition, Journal of Money, Credit, and Banking vol. 16/1984, p. 617-660.

${ }^{8}$ A. Garcia-Herrero, S. Gavila, D. Santabarbara, What explains the low profitability of Chinese banks? Journal of Banking and Finance 33/2009, p. 2080-2092.

${ }^{9}$ X. Fu, Y. Lin, P. Molyneux, Bank competition and financial stability in Asia Pacific. Journal of Banking and Finance vol. 38/2014, p. 64-77.

${ }^{10}$ J. Maudos, J. Fernandez de Guevara, Factors explaining the interest margin in the banking sectors of the European Union, Journal of Banking and Finance vol. 28/2008, p. 2259-2281.

${ }^{11}$ H. Demsetz, Industry structure, market rivalry, and public policy, Journal of Law and Economics vol. 16/1973, p. 1-9.

${ }^{12}$ D. Evanoff, D. Fortier, Reevaluation of the structure-conduct-performance paradigm in banking, Journal of Financial Services Research vol. 1(3)/1988, p. 277-294.
} 
significantly gained their market share due to acquiring banks in a weaker financial condition $^{13}$.

Both MP and ES theories, however, have two different characters and two opposite directions of action. In the MP theory, the market structure is an exogenous factor which affects performance of banks. On the other hand, in the ES theory the market structure is an endogenous factor and is the outcome of decisions made by the banks operating on it. Concentration is therefore an important parameter of the banking activities. It affects, among other things, banks' efficiency, quality of delivered banking services, and innovation in creating new banking products. Among others, Claessens and Laeven indicate that the banking market concentration has significant impact on the availability of banking services (mainly credit) to households and enterprises, which naturally shapes the rate of economic development of the country ${ }^{14}$. Demirguc-Kunt et al. state that a higher banking market concentration increases the cost of financial intermediation ${ }^{15}$.

Research on the relationship between the banking market concentration and bank performance in the CEE countries is rather limited. Andries examined banks operating in seven CEE countries over the period of 2004-2008 and found a growing trend in their efficiency ${ }^{16}$. One of the conclusions of this research is that an increase in the level of banking concentration and bank size positively affects the efficiency of banks. Efthyvoulou and Yildirim assessed the market power and efficiency of banks in 17 CEE countries based on their performance over the period 2002-2010. They noticed a significant variation in these variables in the analyzed countries and a diversified response of banks to the effects of the financial crisis, due, among other factors, to the ownership structure ${ }^{17}$. Most other papers focus rather on assessing the efficiency of banks $^{18}$.

Changes in efficiency are assessed not only in relation to the degree of concentration of the banking market, but also in relation to the level of competition, which is measured by non-structural measures, i.e. the Panzar-Rosse H-statistic ${ }^{19}$, the Lerner index ${ }^{20}$ and the Boone indicator ${ }^{21}$. Non-structural measures often point to

${ }^{13}$ T. Homma, Y. Tsutsui, H. Uchida, Firm growth and efficiency in the banking industry: A new test of the efficient structure hypothesis, Journal of Banking and Finance vol. 40/2014, p. 143-153.

${ }^{14}$ S. Claessens, L. Laeven, What drives bank competition? Some international evidence, Journal of Money, Credit and Banking vol. 36(3)/2004, p. 563-583.

15 A. Demirgüç-Kunt, L. Laeven, R. Levine, Regulations, market structure, institutions, and the cost of financial intermediation, Journal of Money, Credit and Banking vol. 36(3)/2004, p. 593-622.

${ }^{16}$ A. Andries, S. Ursu, Financial crisis and bank efficiency: An empirical study of European banks, Economic Research-Ekonomska Istrazivanija vol. 29(1)/2011, p. 485-497.

${ }^{17}$ G. Efthyvoulou, C. Yildirim, Market power in CEE banking sectors and the impact of the global financial crisis, Journal of Banking and Finance vol. 40/2014, p. 11-27.

${ }^{18}$ G. Anayiotos, H. Toroyan, A. Vamvakidis, The efficiency of emerging Europe's banking sector before and after the recent economic crisis, Financial Theory and Practice vol. 34/2010, p. 247-267; T. Poghosyan, A. Poghosyan, Foreign bank entry, bank efficiency and market power in Central and Eastern European Countries, Economics of Transition vol. 18(3)/2010, p. 571-598; B. Tuskan, A. Stojanovic, Measurement of cost efficiency in the European banking industry, Croatian Operational Research Review vol. 47/2016, p. 47-66.

${ }^{19}$ J. Goddard, J. Wilson, Competition in banking: A disequilibrium approach. Journal of Banking and Finance vol. 33/2009, p. 2282-2292.

${ }^{20}$ Z. Fungacova, L. Solanko, L. Weill, Does competition influence the bank lending channel in the Euro area? Journal of Banking and Finance vol. 49/2014, p. 356-366.

${ }^{21}$ B. Tabak, D. Tazio, D. Cajueiro, The relationship between banking market competition and risk-taking: do size and capitalization matter? Journal of Banking and Finance vol. 36/2012, p. 3366-3381. 
different directions of the relationship between the competition and banks' efficiency. Schaeck and Cihak ${ }^{22}$ analysed the relationship between competition, measured by the Boone indicator, and efficiency using the sample of European countries and US banks in the years 1995-2005. They stated that competition increases due to the increase in the banks' efficiency. Anginer et al. ${ }^{23}$ examined banks in 63 countries in the years 19972009 and found that competition on the banking market, measured by the Lerner index, was negatively correlated with banks profitability. Schaeck et al..$^{24}$ measured competition with the Panzar-Rosse H-statistic and found that having more banking sectors is more stable and efficient. Contrarily, more concentrated sectors are less stable and efficient. They concluded that concentration and competition capture different characteristics of banking sector operations and studies based on these two variables can lead to diverse conclusions.

\section{Data and research methods}

In the research we use the stochastic frontier approach (SFA) to estimate profit inefficiencies for each bank in the sample. We employed the model of Battese and Coelli that provides the estimates of inefficiency in the one-step approach ${ }^{25}$. The profit function is the multi-product translog specification:

$\ln \frac{\operatorname{Prof}_{i t}}{W 3_{i t}}=$

$b_{0}+b_{1} \ln \left(\frac{W 1_{i t}}{W 3_{i t}}\right)+b_{2} \ln \left(\frac{W 2_{i t}}{W 3_{i t}}\right)+b_{3} \ln \left(Q 1_{i t}\right)+b_{4} \ln \left(Q 2_{i t}\right)+b_{5} \frac{1}{2}\left(\ln \left(Q 1_{i t}\right)\right)^{2}+$

$b_{6} \frac{1}{2}\left(\ln \left(Q 2_{i t}\right)\right)^{2}+b_{7} \ln \left(Q 1_{i t}\right) \ln \left(Q 2_{i t}\right)+b_{8} \frac{1}{2}\left(\ln \left(\frac{W 1_{i t}}{W 3_{i t}}\right)\right)^{2}+b_{9} \frac{1}{2}\left(\ln \left(\frac{W 2_{i t}}{W 3_{i t}}\right)\right)^{2}+$

$b_{10} \ln \left(\frac{W 1_{i t}}{W 3_{i t}}\right) \ln \left(\frac{W 2_{i t}}{W 3_{i t}}\right)+b_{11} \ln \left(\frac{W 1_{i t}}{W 3_{i t}}\right) \ln \left(Q 1_{i t}\right)+b_{12} \ln \left(\frac{W 1_{i t}}{W 3_{i t}}\right) \ln \left(Q 2_{i t}\right)+$

$b_{13} \ln \left(\frac{W 2_{i t}}{W 3_{i t}}\right) \ln \left(Q 1_{i t}\right)+b_{14} \ln \left(\frac{W 2_{i t}}{W 3_{i t}}\right) \ln \left(Q 2_{i t}\right)+b_{15} \frac{1}{2} T_{t}^{2}+b_{16} \ln \left(\frac{W 1_{i t}}{W 3_{i t}}\right) T_{t}+$

$b_{17} \ln \left(\frac{W 2_{i t}}{W 3_{i t}}\right) T_{t}+b_{18} \ln \left(Q 1_{i t}\right) T_{t}+b_{19} \ln \left(Q 2_{i t}\right) T_{t}+b_{20} \ln \left(E q_{-} T A_{i t}\right)+$

$b_{21} \ln \left(\frac{W 1_{i t}}{W 3_{i t}}\right) \ln \left(E q_{-} T A_{i t}\right)+b_{22} \ln \left(\frac{W 2_{i t}}{W 3_{i t}}\right) \ln \left(E q_{-} T A_{i t}\right)+b_{23} \ln \left(Q 1_{i t}\right) \ln \left(E q_{-} T A_{i t}\right)+$

$b_{24} \ln \left(Q 2_{i t}\right) \ln \left(E q_{-} T A_{i t}\right)+b_{25} \ln \left(E q_{-} T A_{i t}\right) T_{t}+v_{i t}+u_{i t}$

The dependent variable Prof is measured with a bank Operating Income. We assume that banks have two outputs: Loans (Q1) and Other Financial Assets (estimated as Financial Assets - Net Total Loans) (Q2). The inputs are: (1) Fixed Assets (X1), (2) Labour (X2), and (3) Total Financial Liabilities (X3). The input prices are: (1) Cost of Physical Capital (W1) estimated as sum of Occupancy and Equipment and Depreciation

\footnotetext{
${ }^{22}$ K. Schaeck, M. Cihak, How does Competition Affect Efficiency and Soundness in Banking? New Empirical Evidence. European Central Bank Working Paper No. 932/2008.

${ }^{23}$ D. Anginer, A. Demirguc-Kunt, M. Zhu, How Does Bank Competition Affect Systemic Stability? Policy World Bank Research Working Paper 5981/2012.

24 K. Schaeck, M. Cihak, S. Wolf, Are competitive banking systems more stable? Journal of Money, Credit and Banking vol. 41/2009, p. 711-734.

${ }^{25} \mathrm{G}$. Battese, T. Coell, A model for technical inefficiency effects in a stochastic frontier production function for panel data, Empirical Economics vol. 20/1995, p. 325-332.
} 
of PP\&E divided by Fixed Assets; (2) Cost of Labour (W2) which is Compensation and Benefits Expense over Total Assets; (3) Cost of Funds (W3) calculated by dividing Interest Expense by Total Financial Liabilities. Following Berger and $\mathrm{Mester}^{26}$ and Andries and Ursu ${ }^{27}$ we included also Equity to Total Assets (EqTA) as an input to control for differences across banks' risk preferences. To impose linear homogeneity restrictions, we normalised the dependent variable and all input prices by W3. Finally, we employed time dummy $(\mathrm{T})$ to allow for technological and other time-specific changes, following Lensink, Meesters, and Naaborg ${ }^{28}$, Lozano-Vivas and Pasiouras ${ }^{29}$, and Andries and Ursu ${ }^{30}$. Based on estimating equation (1) we obtained the values of bank profit inefficiency effects $u_{i t}$.

In order to investigate the determinants of bank profit inefficiency across CEE countries, and especially the impact of market concentration, we regress $u_{i t}$ on the range of potential explanatory variables describing the macroeconomic situation, each country's banking sector, and bank-specific situation according to the following specification:

$u_{i t}=\delta_{0}+\delta_{1} g d p_{-}$cap $_{j t-1}+\delta_{2}$ infl $_{j t-1}+\delta_{3}$ loan $_{-} g d p_{j t}+\delta_{4}$ market_share $_{i t}+$ $\delta_{5}$ concentration $_{j t}+\delta_{6}$ perf $_{i t}+\varepsilon_{i t}$

The positive coefficient would mean that the determinant increases bank profit inefficiency, i.e., decreases bank efficiency. Negative sign on a coefficient would mean that efficiency increases. In the equation (2) GDP per capita (gdp_cap) and Inflation (infl) measure income level and change in annual average consumer price level. The ratio of Banking Sector Loans to GDP (loan_gdp) represents the level of financial intermediation in each country. Market Concentration (concentration) is measured with either market share of the 5 largest banks in a country (CR5) or Herfindahl-Hirschman Index (HHI). Individual Bank Market Share (MKTSh) is estimated as a ratio of the bank total assets to total bank assets in a country. Alternatively, we use Bank Size (Size) calculated as the natural logarithm of bank total assets to check the impact of relative and absolute size of a bank on profit inefficiency. In order to control for the bank's safety and performance (perf), we employ Total Capital Ratio (TCR) or use ROAA, ROAE, Cost to Income Ratio (C/I), one at a time.

Further, we were also interested in whether the impact of banking market concentration on profit inefficiency is identical across the CEE countries under analysis. For that we estimated the model with an interaction of concentration measure and individual country dummy. We assume thus that all the other variables extend identical impact across all the countries and that only effects of market concentration might differ:

\footnotetext{
${ }^{26}$ A. Berger, L. Mester, Inside the black box: What explains differences in the efficiencies of financial institutions?, Journal of Banking and Finance vol. 21/1997, p. 895-947.

${ }^{27}$ A. Andries, S. Ursu, Financial crisis and bank efficiency: An empirical study of European banks, Economic Research-Ekonomska Istrazivanija vol. 29(1)/2016, p. 485-497.

${ }^{28}$ R. Lensink, A. Meesters, I. Naaborg, Bank efficiency and foreign ownership: Do good institutions matter?, Journal of Banking and Finance vol. 32/2008, p. 834-844.

${ }^{29}$ A. Lozano-Vivas, F. Pasiouras, The impact of non-traditional activities on the estimation of bank efficiency: International evidence, Journal of Banking and Finance vol. 34/2010, p. 1436-1449.

${ }^{30}$ A. Andries, S. Ursu, Financial crisis and bank efficiency: An empirical study of European banks, Economic Research-Ekonomska Istrazivanija vol. 29(1)/2016, p. 485-497. .
} 
$u_{i t}=\delta_{0}+\delta_{1} g d p_{-}$cap $_{j t-1}+\delta_{2}$ infl $_{j t-1}+\delta_{3}$ loan_ $_{-} g d p_{j t}+\delta_{4}$ market_share $_{i t}+$ $\delta_{5}\left(\right.$ concentration $_{j t} *$ country $\left._{j}\right)+\delta_{6}$ perf $_{i t}+\varepsilon_{i t}$

We also checked whether the impact differs between countries that have and have not adopted the euro with the dummy variable EURO, which takes value 1 for the years since euro adoption, and 0 otherwise:

$u_{i t}=\delta_{0}+\delta_{1} g d p_{-} c a p_{j t-1}+\delta_{2} i n f l_{j t-1}+\delta_{3}$ loan $_{-} g d p_{j t}+\delta_{4}$ market_share $_{i t}+$ $\delta_{5}\left(\right.$ concentration $\left._{j t} * E U R O_{t j}\right)+\delta_{6}$ perf $_{i t}+\varepsilon_{i t}$

All bank-level data are obtained from the SNL database. Data on GDP per capita, rate of inflation, and loans to GDP come from Eurostat while data on market concentration come from ECB Statistical Data Warehouse. All the data are of annual frequency and cover the period from 2005 to 2017. We collected the data on 11 Central and Eastern European countries: Bulgaria (8 banks), Czech Republic (9), Estonia (4), Croatia (14), Hungary (9), Lithuania (6), Latvia (6), Poland (19), Romania (9), Slovenia (3), and Slovakia (7).

\section{Results and discussion}

In the first stage of the research we estimated banks' profit inefficiency scores $u_{i t}$ using the trans-log equation 1 . Table 1 presents values of the average inefficiency and efficiency scores for the individual countries and for individual years.

Table 1. Average profit inefficiency and efficiency scores

\begin{tabular}{|c|c|c|c|c|c|}
\hline Country & $\mathrm{u}^{1}$ & $\mathrm{PE}^{1}$ & Year & $\mathrm{u}^{2}$ & $\mathrm{PE}^{2}$ \\
\hline $\mathrm{BG}$ & $16.2 \%$ & $85.1 \%$ & 2005 & $13.4 \%$ & $87.5 \%$ \\
\hline $\mathrm{CZ}$ & $15.8 \%$ & $85.4 \%$ & 2006 & $14.8 \%$ & $86.3 \%$ \\
\hline $\mathrm{EE}$ & $18.5 \%$ & $83.1 \%$ & 2007 & $17.1 \%$ & $84.3 \%$ \\
\hline $\mathrm{HR}$ & $17.5 \%$ & $84.0 \%$ & 2008 & $20.0 \%$ & $81.8 \%$ \\
\hline $\mathrm{HU}$ & $18.1 \%$ & $83.5 \%$ & 2009 & $19.6 \%$ & $82.2 \%$ \\
\hline $\mathrm{LT}$ & $17.7 \%$ & $83.7 \%$ & 2010 & $18.8 \%$ & $82.9 \%$ \\
\hline LV & $14.5 \%$ & $86.5 \%$ & 2011 & $15.1 \%$ & $86.0 \%$ \\
\hline PL & $21.6 \%$ & $80.6 \%$ & 2012 & $18.6 \%$ & $83.0 \%$ \\
\hline RO & $16.0 \%$ & $85.2 \%$ & 2013 & $22.6 \%$ & $79.8 \%$ \\
\hline SI & $26.9 \%$ & $76.4 \%$ & 2014 & $16.8 \%$ & $84.5 \%$ \\
\hline SK & $12.8 \%$ & $88.0 \%$ & 2015 & $18.0 \%$ & $83.5 \%$ \\
\hline & & 2016 & $16.7 \%$ & $84.6 \%$ \\
\cline { 3 - 6 } & & & 2017 & $19.7 \%$ & $82.1 \%$ \\
\hline
\end{tabular}

Note: Bulgaria - BG, Czech Republic - CZ, Estonia - EE, Croatia - HR, Hungary - HU, Lithuania - LT, Latvia LV, Poland - PL, Romania - RO, Slovenia - SI, Slovakia - SK, ${ }^{1)}$ average for the entire period, ${ }^{2)}$ average over all countries, $\mathrm{u}$ - profit inefficiency score, $\mathrm{PE}$ - profit efficiency score, where $\mathrm{PE}=\exp (-\mathrm{u})$.

Source: Authors'own calculation based on the SNL data.

The results indicate that efficiency of banks in the CEE countries is diverse, from the lowest in Slovenia (76\%) to the highest in Slovakia (88\%) with the average for the region of $84 \%$. Additionally, during the analysed period the CEE banks operated 
with a variable efficiency. The values of efficiency scores for individual years indicate that banks' efficiency falls in the periods of macroeconomic turbulence in 2007-2009 and 2012-2013, and after these periods significantly restores.

In the second stage of the research we checked how the banking market concentration affects banks' inefficiency scores $u_{i t}$, controlling for the impact of some macroeconomic variables and bank characteristics (Table 2). The results confirm the assumption of a significant impact of the market structure on the banks' efficiency. For both measures of concentration, CR5 and HHI, the coefficients in the Models 1 and 2 indicate that banks tend to enjoy higher profit efficiency in more concentrated markets. For a robustness check we regressed efficiency with variables representing the size of the bank (Models 3, 4 and 5) and we received similar results implying that larger banks can achieve higher profit efficiency. Such outcomes can be explained with the ES theory, which states that the more efficient banks become, they increase their market share and concentration of the market ${ }^{31}$.

Table 2. Relation between profit inefficiency scores and macroeconomic and bank individual variables

\begin{tabular}{|c|c|c|c|c|c|c|c|c|}
\hline Variable & Model 1 & Model 2 & Model 3 & Model 4 & Model 5 & Model 6 & Model 7 & Model 8 \\
\hline 1.GDPpc & $\begin{array}{c}0.040 \\
(0.034)\end{array}$ & $\begin{array}{c}0.031 \\
(0.033)\end{array}$ & $\begin{array}{c}0.042^{*} \\
(0.023)\end{array}$ & $\begin{array}{c}0.113^{* * *} \\
(0.036)\end{array}$ & $\begin{array}{l}0.103^{* * *} \\
(0.035)\end{array}$ & $\begin{array}{l}-0.012 \\
(0.021)\end{array}$ & $\begin{array}{l}-0.002 \\
(0.020)\end{array}$ & $\begin{array}{c}0.023^{*} \\
(0.013)\end{array}$ \\
\hline 1.Inflation & $\begin{array}{c}0.006^{*} \\
(0.003)\end{array}$ & $\begin{array}{c}0.006 \\
(0.000) \\
\end{array}$ & $\begin{array}{l}0.006^{* *} \\
(0.003)\end{array}$ & $\begin{array}{l}0.007^{* *} \\
(0.003)\end{array}$ & $\begin{array}{l}0.007^{* *} \\
(0.003)\end{array}$ & $\begin{array}{l}-0.003 \\
(0.002)\end{array}$ & $\begin{array}{c}-0.002 \\
(0.002)\end{array}$ & $\begin{array}{l}0.003^{*} \\
(0.002)\end{array}$ \\
\hline Loan_GDP & $\begin{array}{c}0.001 \\
(0.000)\end{array}$ & $\begin{array}{l}-0.001^{*} \\
(0.000)\end{array}$ & $\begin{array}{l}0.001^{* *} \\
(0.000)\end{array}$ & $\begin{array}{c}-0.001^{* * *} \\
(0.000)\end{array}$ & $\begin{array}{c}-0.001^{* * *} \\
(0.000)\end{array}$ & $\begin{array}{l}-0.001^{* * * *} \\
(0.000)\end{array}$ & $\begin{array}{c}-0.001^{* * *} \\
(0.000)\end{array}$ & $\begin{array}{c}0.001 \\
(0.000)\end{array}$ \\
\hline CR5 & $\begin{array}{c}-0.002^{* * *} \\
(0.001)\end{array}$ & & & $\begin{array}{c}-0.004^{* * *} \\
(0.001)\end{array}$ & & $\begin{array}{c}0.001 \\
(0.000)\end{array}$ & $\begin{array}{l}-0.001 \\
(0.000)\end{array}$ & $\begin{array}{c}0.001 \\
(0.000)\end{array}$ \\
\hline HHI & & $\begin{array}{l}-0.589^{* *} \\
(0.201)\end{array}$ & & & $\begin{array}{l}-0.942^{* * *} \\
(0.243)\end{array}$ & & & \\
\hline MKTSh & & & $\begin{array}{c}-0.353^{* * *} \\
(0.130)\end{array}$ & & & & & \\
\hline Size & & & & $\begin{array}{c}-0.056^{* * *} \\
(0.012)\end{array}$ & $\begin{array}{c}-0.056^{* * *} \\
(0.012)\end{array}$ & & & \\
\hline TCR & $\begin{array}{l}0.005^{* *} \\
(0.002)\end{array}$ & $\begin{array}{l}0.005^{* * *} \\
(0.002)\end{array}$ & $\begin{array}{l}0.005^{* *} \\
(0.002)\end{array}$ & $\begin{array}{l}0.005^{* * *} \\
(0.002)\end{array}$ & $\begin{array}{l}0.005^{* * * *} \\
(0.002)\end{array}$ & & & \\
\hline ROAA & & & & & & $\begin{array}{c}-0.035^{* * *} \\
(0.012)\end{array}$ & & \\
\hline ROAE & & & & & & & $\begin{array}{c}-0.002^{* *} \\
(0.001)\end{array}$ & \\
\hline $\mathrm{C} / \mathrm{I}$ & & & & & & & & $\begin{array}{l}0.005^{* * *} \\
(0.000)\end{array}$ \\
\hline Constant & $\begin{array}{l}-0.124 \\
(0.296)\end{array}$ & $\begin{array}{l}-0.119 \\
(0.294)\end{array}$ & $\begin{array}{l}-0.247 \\
(0.211)\end{array}$ & $\begin{array}{c}0.181 \\
(0.305)\end{array}$ & $\begin{array}{c}0.159 \\
(0.303)\end{array}$ & $\begin{array}{c}0.365^{*} \\
(0.188)\end{array}$ & $\begin{array}{c}0.267 \\
(0.179)\end{array}$ & $\begin{array}{c}-0.303^{* * *} \\
(0.118)\end{array}$ \\
\hline $\mathrm{N}$ & 625 & 625 & 625 & 625 & 625 & 625 & 625 & 625 \\
\hline $\mathrm{R} 2$ & 0.044 & 0.039 & 0.049 & 0.114 & 0.107 & 0.042 & 0.13 & 0.531 \\
\hline F-stat & 2.77 & 2.18 & 4.48 & 5.21 & 4.63 & 4.48 & 5.62 & 40.48 \\
\hline
\end{tabular}

Note: standard error in brackets, ${ }^{* * *},{ }^{* *},{ }^{*}$ represent $1 \%, 5 \%$ and $10 \%$ significance level.

Source: Authors'own calculation based on the SNL data.

${ }^{31}$ The National Bank of Poland reported in 2018 that for some recently in Poland, large banks become more efficient and earn the majority of profits of the banking sector, see: Box 2.5 Concentration of earnings of domestic commercial banks, Financial Stability Report. December 2018. NBP, p. 57-58. 
Referring to the macroeconomic variables the results of the research imply that higher inflation and GDP per capita increase bank profit inefficiency, i.e., decrease the profit efficiency. The level of development of the banking sector affects efficiency of banks in an opposite direction, suggesting that banks perform better in more developed banking sectors and earn higher profits.

Bank efficiency is impacted by banks' individual characteristics in varied ways. Positive coefficient on total capital ratio shows that safer banks tend to have lower profit efficiency, implying a positive effect from the leverage on profits.

Table 3. Relation between profit inefficiency scores and country variables

\begin{tabular}{|c|c|c|c|c|}
\hline Variable & Model 9 & Model 10 & Model 11 & Model 12 \\
\hline 1.GDPpc & $\begin{array}{r}-0.019 \\
(0.046)\end{array}$ & $\begin{array}{r}0.018 \\
(0.022) \\
\end{array}$ & $\begin{array}{r}-0.037 \\
(0.049) \\
\end{array}$ & $\begin{array}{r}0.019 \\
(0.022) \\
\end{array}$ \\
\hline 1.Inflation & $\begin{array}{r}0.004 \\
(0.003) \\
\end{array}$ & $\begin{array}{r}0.005^{*} \\
(0.003) \\
\end{array}$ & $\begin{array}{r}0.004 \\
(0.003) \\
\end{array}$ & $\begin{array}{r}0.006^{*} \\
(0.003) \\
\end{array}$ \\
\hline Loan_GDP & $\begin{array}{r}0.001 \\
(0.001) \\
\end{array}$ & $\begin{array}{l}-0.001^{*} \\
(0.000) \\
\end{array}$ & $\begin{array}{r}0.001 \\
(0.001 \\
\end{array}$ & $\begin{array}{c}-0.001^{* * *} \\
(0.000) \\
\end{array}$ \\
\hline BG x CR & $\begin{array}{r}-0.011^{* * *} \\
(0.004)\end{array}$ & & $\begin{array}{r}-4.445^{* * *} \\
(1.615)\end{array}$ & \\
\hline $\mathrm{CZ} \times \mathrm{CR}$ & $\begin{array}{r}-0.008^{* * *} \\
(0.004) \\
\end{array}$ & & $\begin{array}{l}-2.379^{*} \\
(1.387) \\
\end{array}$ & \\
\hline EE x CR & $\begin{array}{r}-0.007^{* * *} \\
(0.003) \\
\end{array}$ & & $\begin{array}{r}-1.319^{* *} \\
(0.571) \\
\end{array}$ & \\
\hline HR x CR & $\begin{array}{c}-0.009^{* *} \\
(0.003) \\
\end{array}$ & & $\begin{array}{c}-2.621^{* *} \\
(1.104) \\
\end{array}$ & \\
\hline $\mathrm{HU} \mathrm{x} * \mathrm{CR}$ & $\begin{array}{c}-0.010^{* *} \\
(0.004)\end{array}$ & & $\begin{array}{c}-3.254^{* *} \\
(1.628)\end{array}$ & \\
\hline LT x CR & $\begin{array}{c}-0.006^{* *} \\
(0.003)\end{array}$ & & $\begin{array}{l}-1.319^{*} \\
(0.743)\end{array}$ & \\
\hline LV x CR & $\begin{array}{r}-0.010^{* * *} \\
(0.004) \\
\end{array}$ & & $\begin{array}{r}-3.496^{* * *} \\
(1.302) \\
\end{array}$ & \\
\hline PL x CR & $\begin{array}{r}-0.010^{* * *} \\
(0.005) \\
\end{array}$ & & $\begin{array}{r}-3.063 \\
(2.222) \\
\end{array}$ & \\
\hline $\mathrm{RO} \times \mathrm{CR}$ & $\begin{array}{c}-0.011^{* *} \\
(0.004)\end{array}$ & & $\begin{array}{r}-3.628^{* *} \\
(1.471)\end{array}$ & \\
\hline SI x CR & $\begin{array}{c}-0.007^{* *} \\
(0.004)\end{array}$ & & $\begin{array}{r}-1.140 \\
(0.881) \\
\end{array}$ & \\
\hline SK x CR & $\begin{array}{c}-0.009^{* * *} \\
(0.003) \\
\end{array}$ & & $\begin{array}{r}-2.758^{* *} \\
(1.146) \\
\end{array}$ & \\
\hline EURO x CR & & $\begin{array}{l}-0.006^{*} \\
(0.004) \\
\end{array}$ & & $\begin{array}{r}-1.045 \\
(0.675) \\
\end{array}$ \\
\hline TCR & $\begin{array}{r}0.006^{* * *} \\
(0.003\end{array}$ & $\begin{array}{r}0.006^{* * *} \\
(0.002)\end{array}$ & $\begin{array}{l}0.006^{* *} \\
(0.003)\end{array}$ & $\begin{array}{l}0.006^{* *} \\
(0.002)\end{array}$ \\
\hline Constant & $\begin{array}{l}0.755^{* *} \\
(0.401)\end{array}$ & $\begin{array}{r}0.008 \\
(0.196) \\
\end{array}$ & $\begin{array}{r}0.652 \\
(0.414) \\
\end{array}$ & $\begin{array}{r}-0.042 \\
(0.205)\end{array}$ \\
\hline $\mathrm{N}$ & 625 & 625 & 625 & 625 \\
\hline $\mathrm{R} 2$ & 0.081 & 0.059 & 0.076 & 0.047 \\
\hline F-stat & 2.37 & 3.64 & 2.52 & 2.25 \\
\hline
\end{tabular}

Note: standard error in brackets, ${ }^{* * *},{ }^{* *},{ }^{*}$ represent $1 \%, 5 \%$ and $10 \%$ significance level, Models 9 and $10-$ concentration ratio $\mathrm{CR}$ equals to $\mathrm{CR} 5$, Models 11 and 12 - concentration ratio CR equals to HHI.

Source: Authors' own calculation based on the SNL data. 
When it comes to bank performance, higher profitability measured by ROAA and ROAE, and higher cost efficiency $\mathrm{C} / \mathrm{I}^{32}$ (Models 6, 7 and 8) allow banks to achieve higher profit efficiency. It is noteworthy that the R-squared statistic is especially high for the specification with $\mathrm{C} / \mathrm{I}$ ratio showing thus the high importance of banks' operating costs on profit efficiency.

Finally, the results of Models 9 to 12, which check whether the influence of market concentration on bank profit efficiency depends on the specific country under analysis, imply that banking market concentration impact on banks' profit efficiency is similar and statistically significant in all the analysed CEE countries (Table 3). When we use HHI instead of CR5 ratio, the coefficient is not statistically significant in Poland and Slovenia only. There is also no prominent difference in the impact of market concentration between euro area and non-euro area countries.

\section{Conclusions}

This paper studies the relatively rarely described problem of the impact of banking market structure on bank profit efficiency in CEE countries in years 2000-2017. The results show that growing market concentration extends positive impact on the efficiency of the banks operating on this market. Larger bank size and bank market share have a similar effect. Thus, it seems that banks in CEE countries within the studied period could follow the ES theory. Increase in market concentration was endogenous and came from the growing size of the effective banks which crowded out less effective institutions.

Bank profit efficiency is supported by banks' profitable activities, low operation costs relative to incomes, and financial leverage. Furthermore, the efficiency is affected by the external environment, especially the level of banking sector development, price stability, and level of income per inhabitant, represented by GDP per capita. The direction of the impact of macroeconomic variables on efficiency suggest that in countries with lower GDP per capita (including emerging markets) banks operate more efficiently. It thus follows that these countries must be wary of a possible fall in bank efficiency as they continue to grow and should continue monitoring the situation of their banking systems.

\section{References}

Anginer D., Demirguc-Kunt A., Zhu M., How Does Bank Competition Affect Systemic Stability? Policy World Bank Research Working Paper 5981/2012.

Amel D., Barnes C., Panetta F., Salleo C., Consolidation and efficiency in the financial sector: A review of the international evidence. Journal of Banking and Finance vol. 28/2004.

Anayiotos G., Toroyan H., Vamvakidis A., The efficiency of emerging Europe's banking sector before and after the recent economic crisis. Financial Theory and Practice vol. 34/2010.

Andries A., The determinants of bank efficiency and productivity growth in the central and eastern European banking systems. Eastern European Economics vol. 49(6)/2011.

Andries A., Ursu S, Financial crisis and bank efficiency: An empirical study of European banks. Economic Research-Ekonomska Istrazivanija vol. 29(1)/2016.

Avkiran N., The evidence on efficiency gains: The role of mergers and the benefits to the public. Journal of Banking and Finance vol. 23(7)/1999.

${ }^{32}$ Lower values of cost-to-income ratio $\mathrm{C} / \mathrm{I}$ indicate higher cost efficiency. 
Avramidis P., Cabolis Ch., Serfes K., Bank size and market value: The role of direct monitoring and delegation costs. Journal of Banking and Finance vol. 93/2018.

Bain J., Relation of Profit Rates to Industry Concentration. Quarterly Journal of Economics vol. 55/1951.

Battese G., Coelli T., A model for technical inefficiency effects in a stochastic frontier production function for panel data. Empirical Economics vol. 20/1995.

Berger A., The profit-structure relationship in banking - tests of market-power and efficientstructure hypotheses. Journal of Money, Credit and Banking vol. 27/1995.

Berger A., Demsetz R., Strahan P., The consolidation of the financial services industry: Causes, consequences, and implications for the future. Journal of Banking and Finance vol. 23/1999.

Berger A., Hannan T., The Price-Concentration Relationship in Banking. The Review of Economics and Statistics vol. 71/1989.

Berger A., Mester L., Inside the black box: What explains differences in the efficiencies of financial institutions? Journal of Banking and Finance vol. 21/1997.

Berger A., Hasan I., Zhou M., Bank ownership and efficiency in China: what will happen in the world's largest nation? Journal of Banking and Finance vol. 33/2009.

Bikker J., Haaf K., Competition, concentration and their relationship: An empirical analysis of the banking industry. Journal of Banking and Finance vol. 26 (11)/2002.

Casu B., Girardone C., Bank competition, concentration and efficiency in the single European market. The Manchester School vol. 74(4)/2002.

Claessens S., Laeven L., What drives bank competition? Some international evidence. Journal of Money, Credit and Banking vol. 36(3)/2004.

Demirgüç-Kunt A., Laeven L., Levine R., Regulations, market structure, institutions, and the cost of financial intermediation. Journal of Money, Credit and Banking vol. 36(3)/2004.

Demsetz H., Industry structure, market rivalry, and public policy. Journal of Law and Economics vol. $16 / 1973$

Duygun M., Sena V., Shaban M., Schumpeterian competition and efficiency among commercial banks. Journal of Banking and Finance vol. 37/2013.

Efthyvoulou G., Yildirim C., Market power in CEE banking sectors and the impact of the global financial crisis. Journal of Banking and Finance vol. 40/2014.

Financial Stability Report. December 2018, The National Bank of Poland, Warsaw 2018.

Fu X., Lin Y., Molyneux P., Bank competition and financial stability in Asia Pacific. Journal of Banking and Finance vol. 38/2014, p. 64-77.

Fungacova Z., Solanko L., Weill L., Does competition influence the bank lending channel in the Euro area? Journal of Banking and Finance vol. 49/2014, p. 356-366.

Garcia-Herrero, A., Gavila, S., Santabarbara, D., What explains the low profitability of Chinese banks? Journal of Banking and. Finance vol. 33/2009, p. 2080-2092.

Gilbert R., Bank market structure and competition. Journal of Money, Credit, and Banking vol. 16/1984.

Haynes M., Thompson S., The productivity effects of bank mergers: Evidence from the UK building societies. Journal of Banking and Finance vol. 23/1999.

Homma T., Tsutsui Y., Uchida H., Firm growth and efficiency in the banking industry: A new test of the efficient structure hypothesis. Journal of Banking and Finance vol. 40/2014.

Koutsomanoli-Filippaki A., Margaritis D., Staikouras C., Efficiency and productivity growth in the banking industry of Central and Eastern Europe. Journal of Banking and Finance vol. 33/2009.

Koutsomanoli-Filippaki A., Staikouras C., Competition and concentration in the New European banking Landscape. Working Paper Department of Accounting and Finance, Athens University of Economics and Business 2014, Greece.

Lensink R., Meesters A., Naaborg I., Bank efficiency and foreign ownership: Do good institutions matter? Journal of Banking and Finance vol. 32/2008. 
Lozano-Vivas A., Pasiouras F., The impact of non-traditional activities on the estimation of bank efficiency: International evidence. Journal of Banking and Finance vol. 34/2010.

Mamatzakis E., Matousek R., Vu A.N., What is the impact of bankrupt and restructured loans on Japanese bank efficiency? Journal of Banking and Finance vol. 72/2017.

Mason E., Price and Production Policies of Large-Scale Enterprise. American Economic Review vol. 29(1)/1939.

Maudos J., Fernandez de Guevara J., Factors explaining the interest margin in the banking sectors of the European Union. Journal of Banking and Finance vol. 28/2014, p. 2259-2281.

Mesa R., Sánchez H., Sobrino J., Main determinants of efficiency and implications on banking concentration in the European Union. Spanish Accounting Review vol., 17(1)/2014.

Niţoi M., Spulbar C., An Examination of Banks' Cost Efficiency in Central and Eastern Europe. Procedia Economics and Finance vol. 22/2015.

Peng J., Jeng V., Wang J., Chen Y., The impact of bancassurance on efficiency and profitability of banks: Evidence from the banking industry in Taiwan. Journal of Banking and Finance vol. 80/2017.

Poghosyan T., Poghosyan A., Foreign bank entry, bank efficiency and market power in Central and Eastern European Countries. Economics of Transition vol. 18(3)/2010.

Rhoades S., Efficiency effects of horizontal (in-market) bank mergers. Journal of Banking and Finance vol. 17(2-3)/1993.

Schaeck K., Cihak M., How does Competition Affect Efficiency and Soundness in Banking? New Empirical Evidence. European Central Bank Working Paper No. 932/2008.

Schaeck K., Cihak M., Wolf S., Are competitive banking systems more stable? Journal of Money, Credit and Banking vol. 41/2009, p. 711-734.

Silva T., Guerra S., Tabak B., de Castro Miranda R., Financial networks, bank efficiency and risktaking. Journal of Financial Stability vol. 25(C)/2016.

Tabak B., Tazio D., Cajueiro D., The relationship between banking market competition and risktaking: do size and capitalization matter? Journal of Banking and Finance vol. 36/2012, p. 33663381 .

Tuskan B., Stojanovic A., Measurement of cost efficiency in the European banking industry. Croatian Operational Research Review vol. 47/2016.

\section{Efektywność banków a koncentracja sektora bankowego w krajach EŚW}

\section{Streszczenie}

Zależność między strukturą rynku bankowego a efektywnością banków jest przedmiotem wielu badań od kilku dziesięcioleci. Większość $\mathrm{z}$ nich wskazuje na dodatnią korelację między tymi zmiennymi. Celem badania jest zbadanie tej relacji dla 96 banków działających w jedenastu krajach Europy Środkowo-Wschodniej w latach 2005-2017. Efektywność banków jest wyznaczana przy pomocy metody SFA a następnie poddana regresji względem czynników makroekonomicznych i indywidualnych dla banków. Wyniki badania wskazują, że na efektywność banków pozytywnie wpływa koncentracja rynku, a także wielkość ich aktywów. Zależność ta jest obecna we wszystkich badanych krajach. Dodatkowo stwierdzono, że na efektywność banków pozytywnie wpływa rozwój systemu bankowego. Natomiast przeciwnie, PKB pc, stopa inflacji i współczynnik kapitałowy banku nie sprzyjają wydajności banków. 
Słowa kluczowe: kraje EŚW, bank, efektywność, koncentracja rynku JEL codes: G10, G15, G21

Information about authors:

\section{Sylwester Kozak, dr hab.}

Warsaw University of Life Sciences - SGGW

166 Nowoursynowska Str.,

02-798 Warsaw,

e-mail: sylwester_kozak@sggw.pl,

ORCID: 0000-0001-9485-6704.

Agata Wierzbowska, dr

Kobe University

2-1 Rokkodai-cho, Nada-ku, Kobe,

Japan,

e-mail: wierzbowska@econ.kobe-u.ac.jp,

ORCID: 000-0001-8641-3217. 